\title{
Species Diversity of Non-Volant Small Mammals Between Lowland and Highland of Gunung Serapi, Kubah National Park, Sarawak
}

\author{
HAZIQ IZZUDDIN MUHAMAD AZMAN ${ }^{1}$, ROBERTA CHAYA TAWIE TINGGA*2 \& \\ MADINAH ADRUS ${ }^{1}$
}

\author{
${ }^{1}$ Faculty of Resource Science and Technology, Universiti Malaysia Sarawak, 94300 Kota Samarahan, Sarawak, \\ Malaysia; ${ }^{2}$ Centre for Pre-University Studies, Universiti Malaysia Sarawak, 94300 Kota Samarahan, Sarawak, \\ Malaysia \\ *Corresponding author: trctawie@unimas.my \\ Received: 22 February $2021 \quad$ Accepted: 9 July $2021 \quad$ Published: 31 December 2021
}

\begin{abstract}
The study of non-volant small mammals was conducted at Kubah National Park (KNP), Sarawak for eight days between November 2018 until February 2019. The objective of this study was to determine the species diversity of non-volant small mammals at the highland (>750 - $805 \mathrm{~m}$ a.s.1.) and lowland (<200 $\mathrm{m}$ a.s.1.) at KNP. The elevation of Gunung Serapi is $911 \mathrm{~m}$ a.s.l. but the highest accessible area is at $805 \mathrm{~m}$ a.s.l. The distance between two sampling sites is approximately $4.5 \mathrm{~km}$. Humidity and temperature measurement were also recorded at both sites. A total of 50 cage traps were set up at the highland and 50 cage traps at the lowland. The baits that were used in this study were oil palm and banana. A total of 26 individuals from 11 species, eight genera and four families were captured. However, there is no significant difference in species diversity between low and high elevations because the elevation of KNP was not high enough to distinguish species that are highland or lowland specialist.
\end{abstract}

Keywords: Abundance, diversity, elevations, Kubah National Park, non-volant small mammals

Copyright : This is an open access article distributed under the terms of the CC-BY-NC-SA(Creative Commons Attribution-NonCommercial-ShareAlike 4.0 International License) which permits unrestricted use, distribution, and reproduction in any medium, for non-commercial purposes, provided the original work of the author(s) is properly cited

\section{INTRODUCTION}

Non-volant small mammals are categorized as mammals that are incapable of flying. These animals are grouped as small mammals where the adult weight of the body is less than $1000 \mathrm{~g}$ (Lim \& Pacheco, 2016). In Borneo, there are approximately 288 species of mammals reported whereby, 182 species belong to small mammal. Both order Chiroptera (102 species) and Rodentia (61 species) are the most dominant small mammals. Although Borneo consists of the largest biodiversity in Southeast Asia, excessive logging has significantly brought down the number individuals of non-volant small mammals (Wells et $a l .$, 2007). Their study also stated that, the species diversity and species richness of non-volant small mammals were lower in logged forest compared to unlogged forest.

The type of fauna surrounding the forest can be estimated by identifying the non-volant small mammal species and its food through their feces (Wells et al., 2009). Chen et al. (2017a) concluded that small mammals are important for the forest landscape and environment because they act as seed dispersers. Hence, the decreasing number of non-volant small mammals will decrease the distribution of seed for several plant species in the forest. Other than that, non-volant small mammals are also consumers of small invertebrate (Heaney, 2001; Chen et al., 2017a) such as insect. Thus, they played a role in controlling the insect populations (Jones et al., 1998). Apart from being the predator, they also play an important part in a local food chain for larger animal such as hawk and owl (William \& Fargo, 2002).

Climate is one of the factors whereby both the temperature and humidity can affect the species richness of certain organisms. The higher the temperature, the higher the number of species there is (McCain \& Grytnes, 2010). It indicates that nonvolant small mammals are more favorable to the habitat with higher temperature. Norton (1985) reported, that temperature will change about $9.8^{\circ} \mathrm{C}$ per $1000 \mathrm{~m}$. The faunas from two different altitudes can also be the benchmark for the different range 
of species diversity. The different types of plant at higher elevation perhaps may be able to differentiate the species of non-volant small mammals (Körner, 2007). Furthermore, the vegetation type can be connected to the availability of food resources to those organisms.

Due to these factors, it is important to conduct a study about the differences in species diversity between highland and lowland of the selected mountain, Gunung Serapi. There have been numerous studies in these topics, but the importance of conservation among Sarawak resident in terms of enforcement and awareness is currently very low. Sarawak is ranked $12^{\text {th }}$ for its unique and diversity of species by National Biodiversity Index in 2008. However, excessive human activities have decreased the biodiversity from year to year. Kamri (2013) reported that from 2002 to 2009, Malaysia has the highest rate of plant extinction in Asia. Forest in Borneo has decreased by $10.2 \%$ via deforestation and land degradation every year (Hon \& Shibata, 2013).

This study also can aid the conservation efforts by focusing on a specific area that become the habitat for rare and endangered species apart as revision for future conservation management purposes in this area. It helps different stake holders in better understanding of flora and fauna habitat in various altitudes so that any development around a particular area can be well-managed in the future. Thus, several samples of non-volant small mammals were collected at two elevations to compare their species diversity at Gunung Serapi.

\section{METHODOLOGY}

\section{Sampling Sites}

The sampling sites of this study were at Gunung Serapi in Kubah National Park (KNP), Kuching, Sarawak (1 $\left.{ }^{\circ} 36^{\prime} 45.0^{\prime \prime} \mathrm{N} 110^{\circ} 11^{\prime} 45.6^{\prime \prime E}\right)$. The area of this park is about 2230 ha and the elevation of this mountain peak is approximately $911 \mathrm{~m}$. This mountain is covered by secondary forest and generally, most of the vegetation is from the Dipterocarpaceae family (Palmiotto et al., 2004). This national park was established because of its various species of endemic palms. The sampling sites were categorized into highland and lowland following Caceres et al. (2011). The elevation of lowland site was approximately $150 \mathrm{~m}-200 \mathrm{~m}$ a.s.l. at the Main trail ( $\left.1^{\circ} 36^{\prime} 46.1^{\prime \prime N} 110^{\circ} 11^{\prime} 50.7^{\prime \prime E}\right)$, while the highland site was approximately $750 \mathrm{~m}$
- $805 \mathrm{~m}$ a.s.l. at the Summit trail $\left(1^{\circ} 35^{\prime} 17.2^{\prime \prime} \mathrm{N}\right.$ $\left.110^{\circ} 11^{\prime} 41.3^{\prime \prime} \mathrm{E}\right)$, which is the highest accessible area. The distance between these two sampling sites were approximately $4.5 \mathrm{~km}$ by using the trekking trails. The lowland sampling site consists of numerous types of palm flora. The trees are mostly taller and has bigger root. Larger leaf size reduces the light penetration to understory resulted in only seedlings, climbers and sapling trees growing between the forest canopy and ground cover. The highland is Kerangas, ridge top and lower montane forest (Hazebroek \& Abang Morshidi, 2000). Most of the vegetation on the highland have smaller leaf size compared to those in lowland.

\section{Sampling Method}

A total of 100 cage traps were deployed in this study. Baited cage traps were mostly placed on the ground near or inside fallen logs, close to hole-like structure on the ground and near a trench that potentially serves as water resource. The traps were placed following a line transect design with a distance of $50 \mathrm{~m}$ long. One transect line had five stations that consist of ten cage traps. The distance between one cage trap and the another is approximately five meters. To avoid disturbance especially from tourists, the cage trap was set up approximately five meters horizontally away from the trails. A total of 50 cage traps were set up at highland 750 - $805 \mathrm{~m}$ a.s.l. of Gunung Serapi meanwhile another 50 cage traps were setup at lowland 150 - $200 \mathrm{~m}$ a.s.l. The study period was eight nights with a total effort of 400 trap-nights for each sampling sites. The cage trap was checked at $9.00 \mathrm{am}$ and in the evening at $4.00 \mathrm{pm}$ every day during the study period. The baits used in this study to attract the non-volant small mammals were fruits that have good smell and bright in colour such as oil palm fruitlet and banana. The oil palm fruitlet was burned before being used as a bait to increase the odour. The baits were replaced regularly. The animals that were caught in the cage trap were put inside cloth bag and brought back to the basecamp for identification process. Species identification was based on Phillips \& Phillips (2016) and Payne et al. (2005).

\section{Abiotic measurement}

Environmental parameters recorded in both sampling sites were the temperature, humidity and altitude. During the sampling period, the abiotic factors readings were recorded every day. The Log 
Tag Recorder was used to measure temperature and humidity, while Global Positioning System (Garmin GPS 73) was used to pinpoint location and determine elevation.

\section{Statistical Analysis}

The sampling data was analyzed by using $\mathrm{R}$ statistical software version 4.0.5 (R Core Team, 2017). Shannon Diversity in the $R$ packages "iNEXT" (Hsieh et al., 2016) was used to determine species diversity. Pielou evenness index was used to estimate species evenness. While for species richness, Margalef richness index was used. Rarefaction curve was computed using $\mathrm{R}$ package "ggplot2" (Wickham, 2011). The t-test was used to determine whether there is a significant difference between species diversity of highland and lowland areas by using Past software (Hammer et al., 2001). If the $\mathrm{p}$ value is less than 0.05 , the diversity is considered significantly different.

\section{RESULTS}

A total of 26 individuals of non-volant small mammals belonging to 11 species in eight genera and four families were caught during this study (Table 1). The number of individuals caught at both lowland and highland was 13 each. In this study, with four individuals each, Maxomys rajah, M. whiteheadi, Leopoldamys sabanus, and Rattus exulans had the highest abundance, followed by Tupaia montana, T. tana, and Sundamys muelleri with two individuals each, and Niviventer cremoriventer, T. gracilis, Sundasciurus lowii, and Echinosorex gymnura with only one (Table 1). Based on the 2020 IUCN Red List, nine species were listed under least concern category while the other two species were listed as vulnerable.

Based on Figure 1, the number of species captured at lowland KNP was horizontal starting from the $6^{\text {th }}$ sampling day. This indicates there was no new recorded species found, hence the species accumulation curve has reached asymptote. The number of species captured remain increasing at the 8th sampling day at highland KNP. This increasing pattern indicated that if the number of sampling days were extended and sampling sites were added, more species may be captured.

Based on Table 2, the Shannon species diversity index ( $\left.\mathrm{H}^{\prime}\right)$ for the highland is higher than the lowland. For the species richness index (D), the value between highland and lowland was similar.
The species evenness index $(\mathrm{J}$ ') showed that, the highland has higher value than the lowland. Both sampling sites caught the same number of species which is eight. There was no significant difference in all the species diversity indices of non-volant small mammals $(p=0.978, p>0.05)$ between highland and lowland in KNP.

In comparison to the number of individuals, Shannon species diversity at the highlands is higher than at the lowlands (Figure 2). Rarefaction estimates that species diversity will increase with number of individuals in both area (Figure 2). It indicates that even if sampling sites in lowland reached asymptote in species accumulation curve (Figure 1), by increasing the number of sampling days, the species diversity and number of individuals may increase.

The average of environmental data collected throughout the study period between highland and lowland was slightly different. The temperature for lowland was $24.77{ }^{\circ} \mathrm{C}$ while the humidity was $98.81 \% \mathrm{RH}$. The temperature and humidity was lower than the expected measurement possibly because of the rainy seasons along the study period. For the highland, the temperature was $21.52{ }^{\circ} \mathrm{C}$ and the humidity was $98.13 \% \mathrm{RH}$.

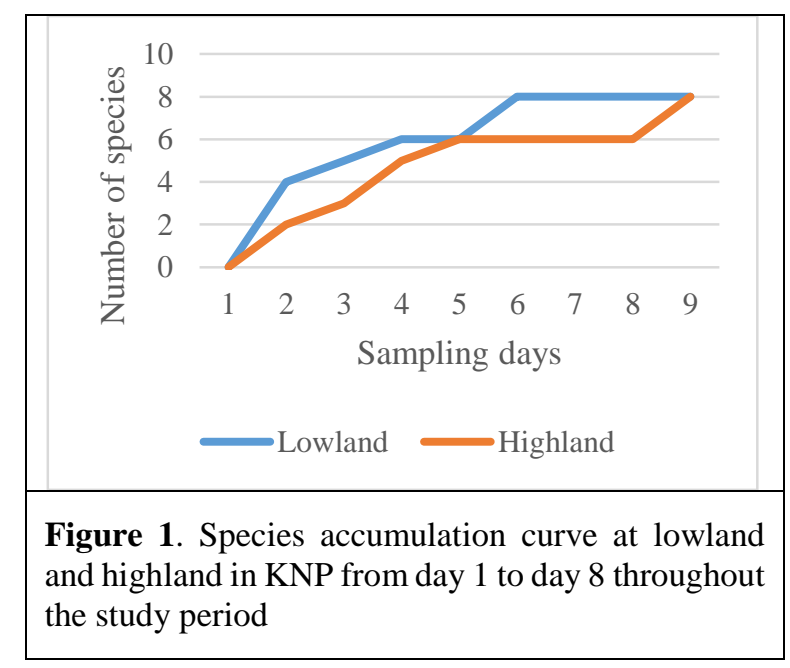

\section{DISCUSSION}

Most samples caught were from family Muridae with a total of 19 individuals. The result from this study showed that there was no significant difference in species diversity between highland and lowland as most of the non-volant small mammals species caught were present in both 
Table 1: Summary of small mammals captured in Kubah National Park

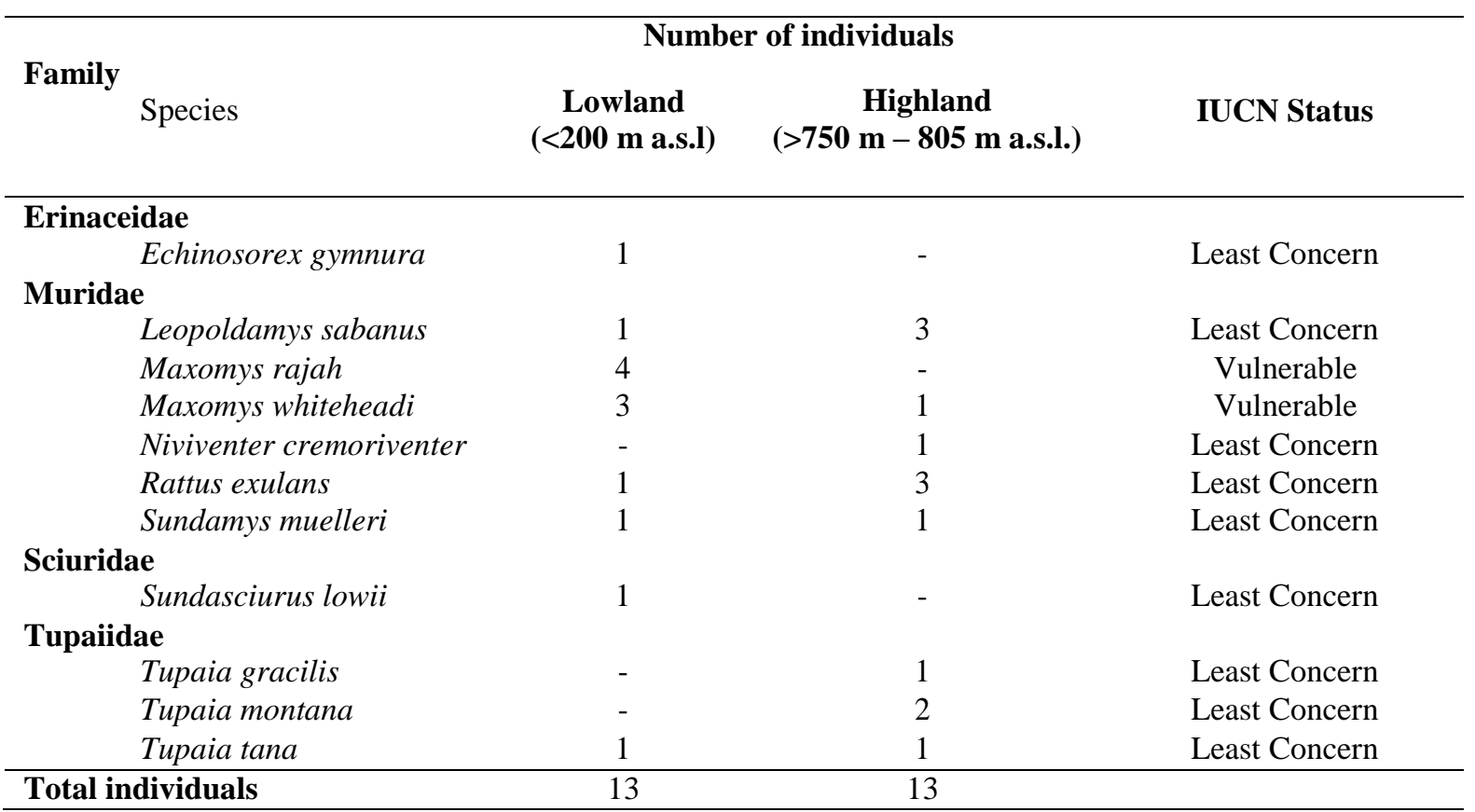

Table 2: The Shannon diversity index (H'), species richness index (D) and the number of species (N) at highland $(750 \mathrm{~m}-805 \mathrm{~m})$ and lowland $(150 \mathrm{~m}-200 \mathrm{~m})$

\begin{tabular}{lll}
\hline Elevation & Lowland & Highland \\
\hline $\mathrm{H}^{\prime}$ & 1.885 & 1.951 \\
$\mathrm{D}$ & 2.729 & 2.729 \\
$\mathrm{~J}$ & 0.906 & 0.938 \\
$\mathrm{~N}$ & 8 & 8 \\
\hline $\mathrm{p}=0.97813$ & & \\
\hline
\end{tabular}

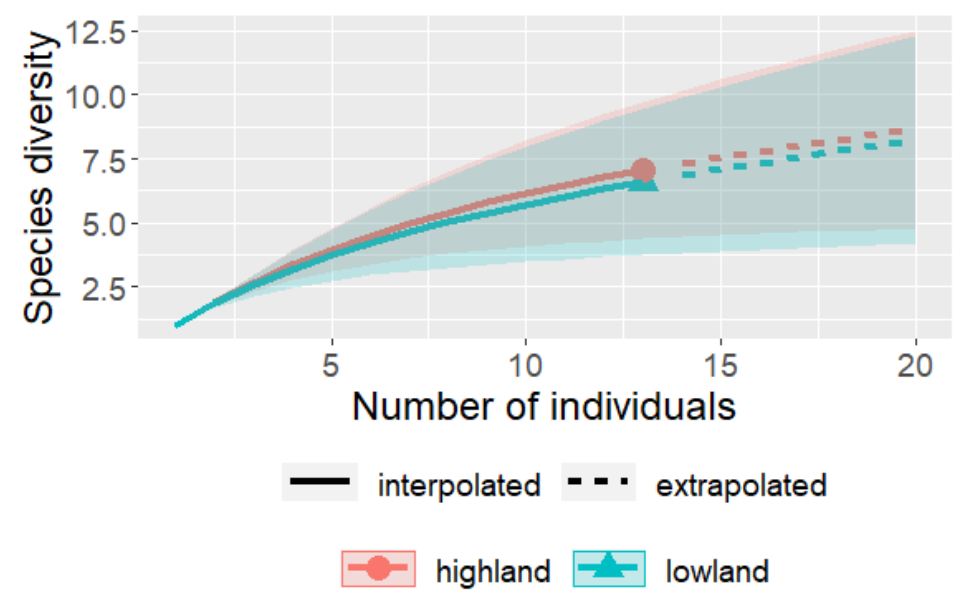

Figure 2. The species diversity rarefaction curves for non-volant small mammals between highland and lowland combined over 8 days of sampling days 
elevations. Gunung Serapi may not be high enough to allow distinguishing species that are highland or lowland specialist. The exact distance travelled by non-volant small mammals are still in study. According to Wen et al. (2016), the dispersal of non-volant small mammals depends on the geographical features of the area and the travelling ability of the species itself. For example, the squirrel species travelled mostly depends on the trees (Lurz et al., 1997), meaning the absence of tree in a particular area can make the dispersal become difficult for them. However, in KNP, most of the area were covered by trees so basically for those species whose lives depend on trees can travel almost to everywhere in KNP.

Maxomys whiteheadi, L. sabanus, $R$. exulans, T. tana and $S$. muelleri were generally found all over the elevation (Heideman et al., 1987; Nor, 2001). Somehow during this study, M. rajah and $S$. lowii were only found at the lowland at KNP. But according to Langham (1983) and Nor et al. (2001), these two species were also found at highland and lowland in Gunung Jerai and Gunung Kinabalu. The same goes for $N$. cremoriventer that can be found all over the elevations (Nor et al., 2001). Meanwhile in KNP, T. gracilis was only found at the highland. However, Helgen (2005) stated, it can be found below $1200 \mathrm{~m}$ a.s.l. which means it can also be encountered in both elevations. This indicates that most of the species that captured during this study were the species that lived and distributed at both elevations. Only $E$. gymnura that was encountered at the lowland (Batin et al., 2002) while T. montana was encountered at the highland (Nor, 2001) which only lived higher than $300 \mathrm{~m}$ a.s.l. This result is congruent in why there were no significant differences between species diversity at highland and lowland in KNP.

The capture rate over the eight-night study period was only $3.25 \%$ (Theuerkauf et al., 2011). Based on the relative humidity recorded, the data was almost dew point $(100 \% \mathrm{RH})$ which means the possibility of rain was high (Umoh et al., 2013). Heaney (2001) stated, the lowland received more rainfall than highland. This statement explained the relative humidity data at the highland $(98.13 \%)$ that is slightly lower from the lowland $(98.81 \%)$.

The rainfall has resulted in a low capture rate of non-volant small mammals (Dickman et al., 1999; Khan et al., 2017). Most of our sampling days were rainy days because of the rainy seasons. This also causes the bait to rot faster, and the odour becomes weaker. As a result, non-volant small mammals are less attracted to the bait. To increase the catch rate and number of species caught, the study needs to use pitfall trap method as well to target shrews and other small mammals that live at the forest floor (Khan et al., 2017), increase the number of sampling days, sampling during sunny season and diversify the area for deploying catch traps to represent different microhabitat (Jayaraj et al., 2013).

Based on the study by Grytnes and Beaman, (2006), the species richness of the plant at $300 \mathrm{~m}$ to $900 \mathrm{~m}$ has not much different. Plant species richness has been reported to play an important role in determining species richness of small mammals (Chen et al., 2017b). So, it is possible for the nonvolant small mammals that were caught in this study that feed on a certain type of seeds to get the food resources at any elevation in KNP. This resulted in same value of species richness between lowland $(\mathrm{D}=2.729)$ and highland $(\mathrm{D}=2.729)$. Zenkova and Rapoport (2011) stated the abundance of earthworms starts to decrease at the alpine zone which is food resources for some non-volant small mammals species. Hence, the number of species encountered at highland should be lower than at the lowland. Unfortunately, Gunung Serapi was only $805 \mathrm{~m}$ a.s.l. which not high enough to have this alpine zone (2900 m a.s.l. and above) (Jayaraj et al., 2006) that resulted in same number of species encounter for both highland and lowland in this study. However, it potentially records unique species composition between lowland and sub montane area.

The major factors that influence the species distribution at different altitudes are temperature and humidity (Kluge et al., 2006). The higher species diversity can be found mostly in the warmer and drier conditions against the cooler and wetter condition (Nor, 2001). Throughout the study period, the data collected for average temperature and average relative humidity recorded was 24.77 ${ }^{\circ} \mathrm{C}$ and $98.81 \% \mathrm{RH}$ for the lowland while $21.52{ }^{\circ} \mathrm{C}$ and $98.13 \% \mathrm{RH}$ for the highland. In contrast, Stevens and Husband (1998) stated that species diversity increases when the air temperature becomes lower and humidity becomes higher.

However, based on the data, there was a very slight difference between temperature and humidity recorded. This resulted and supported in low differences of species diversity from the sample 
collected between highland $\left(\mathrm{H}^{\prime}=1.951\right)$ and lowland $\left(\mathrm{H}^{\prime}=1.885\right)$.

The diverse microhabitat provided by the primary forest's diversity have generally provide suitable surrounding for the insect (Richards et al., 1996). However, both sampling sites were located in secondary forest which may result in low number of insect diversity. Some of the invertebrates only chose selected trees or plants that are suitable for their larval diet (Schulze et al., 2001) which makes some of them only abundance in selected area. Perhaps, the undisturbed non-trails forest deeper inside KNP can provide numerous types of vegetation can be resulting in higher number of non-volant small mammal species (Clements et al., 2014).

Lastly, the recommendation for studying diversity in different elevations is to increase more sampling sites and wider the elevations so the number of species encounters can be increase. Another recommendation is to plan a proper sampling date to avoid rainy seasons so the catch rate can be increased.

\section{CONCLUSION}

As a conclusion, the abundant species of nonvolant small mammals caught in KNP were $M$. rajah, $M$. whiteheadi, $L$. sabanus and $R$. exulans. Most of them can be found at highland and lowland of KNP. It can be concluded that the species diversity and species richness of non-volant small mammals between highland and lowland is not significantly different. The major reason was the height of Gunung Serapi was not high enough to distinguish the species that live specifically either at highland or lowland. More sampling required to further validate the effect of both temperature and humidity. This study is important for conservation purposes as the evidence which the non-volant small mammal species that was discovered in the past can still be found in current days.

\section{ACKNOWLEDGEMENT}

We would like to thank the Faculty of Resource Science and Technology, Universiti Malaysia Sarawak and Sarawak Forest Department for the permission [(281)JHS/NCCD/600-7/2/107 and WL140/2018] to conduct this study.

\section{REFERENCES}

Batin, Z., Nor, S.M. \& Ahmad, M.Y. (2002). Influence of elevational habitat changes on non-volant small mammal species distribution and diversity on Mount Nuang, Hulu, Langat, Selangor Malaysia. Pakistan Journal of Biological Sciences, 5(8): 819-824.

Caceres, N.C., Godoi, M.N., Hannibal, W. \& Ferreira, V.L. (2011). Effects of altitude and vegetation on small- mammal distribution in the Urucum Mountains, western Brazil. Journal of Tropical Ecology, 27(3): 279- 287.

Chen, W., Zhong, J., Sun, S., Xie, Z. \& Zhou, Y. (2017a). Fuelwood collection depresses the seeddispersal service provided by rodents. Forest Ecology and Management, 406: 53-60.

Chen, Z., He, K., Cheng, F., Khanal, L., \& Jiang, X. (2017b). Patterns and underlying mechanisms of non-volant small mammal richness along two contrasting mountain slopes in southwestern China. Scientific Reports, 7: 13277.

Clements, G.R., Lynam, A.J., Gaveau, D., Yap, W.L., Lhota, S. Goosem, M., Laurance, S. \& Laurance, W.F. (2014). Where and how are roads endangering mammals in Southeast Asia's forests? PloS One, 9(12): e115376.

Dickman, C.R., Mahon, P.S., Masters, P. \& Gibson, D.F. (1999). Long-term dynamics of rodent populations in arid Australia: the influence of rainfall. Wildlife Research, 26(4): 389-403.

Grytnes, J.A. \& Beaman, J.H. (2006). Elevational species richness patterns for vascular plants on Mount Kinabalu, Borneo. Journal of Biogeography, 33(10): 1838-1849.

Hammer, Ø., Harper, D.A. \& Ryan, P.D. (2001). PAST: Paleontological statistics software package for education and data analysis. Palaeontologia Electronica, 4(1): 9.

Hazebroek, H.A. \& Abang Morshidi, A.K. (2000). National Parks of Sarawak. Kota Kinabalu, Sabah: Natural History Publications (Borneo).

Heaney, L.R. (2001). Small mammal diversity along elevational gradients in the Philippines: An assessment of patterns and hypotheses. Global Ecology and Biogeography, 10(1): 15-39.

Heideman, P.D., Heaney, L.R., Thomas, R.L. \& Erickson, K.R. (1987). Patterns of faunal diversity 
and species abundance of non-volant small mammals on Negros Island, Philippines. Journal of Mammalogy, 68(4): 884-888.

Helgen, K.M. (2005). Order Scandentia. Mammal species of the world: A taxonomic and geographic reference. In Wilson D.E. \& Reeder D.M., (eds.). 3rd ed. Johns Hopkins University Press, Baltimore, Maryland, Pp. 104-109.

Hon, J. \& Shibata, S. (2013). A review on land use in the Malaysian state of Sarawak, Borneo and recommendations for wildlife conservation inside production forest environment. Borneo Journal of Resource Science and Technology, 3(2): 22-35.

Hsieh, T.C. Ma, K.H. \& Chao, A. (2016). iNEXT: An $\mathrm{R}$ package for rarefaction and extrapolation of species diversity (H ill numbers). Methods in Ecology and Evolution, 7(12): 1451-1456.

IUCN 2020. The IUCN Red List of Threatened Species. http://www.iucnredlist.org. Downloaded on 24 August 2020

Jayaraj, V.K., Abdullah, M.T., Khan, F.A. \& Ketol, B. (2006). Bat survey of Mount Penrisen and notes on the rare Kerivoula minuta, Kerivoula intermedia and Hipposideros coxi in Sarawak, Borneo. Journal of Biological Sciences, 6(4): 711-716.

Jayaraj, V.K., Daud, S.H.M., Azhar, M.I., Sah, S.A.M., Mokhtar, S.I. \& Abdullah, M.T. (2013). Diversity and conservation status of mammals in Wang Kelian state Park, Perlis, Malaysia. Check List, 9(6): 14391448.

Jones, C.G., Ostfeld, R.S., Richard, M.P., Schauber, E.M. \& Wolff, J.O. (1998). Chain reactions linking acorns to gypsy moth outbreaks and Lyme disease risk. Science, 279(5353): 1023-1026.

Kamri, T. (2013). Willingness to pay for conservation of natural resources in the Gunung Gading National Park, Sarawak. Procedia-Social and Behavioral Sciences, 101: 506-515.

Khan, F.A.A., Tahir, N.F.D.A., Rahman, S.P.H., Dee, J.W., Morni, M.A., Rosli, Q.S., Tingga, R.C.T., Rahman, M.R.A. \& Azhar, I. (2017). Small mammals from Samunsam Wildlife Sanctuary, Sarawak, Malaysian Borneo. Borneo Journal of Resource Science and Technology, 7(2): 98-106.

Kluge, J., Kessler, M., \& Dunn, R.R. (2006). What drives elevational patterns of diversity? A test of geometric constraints, climate and species pool effects for pteridophytes on an elevational gradient in Costa Rica. Global Ecology and Biogeography, 15(4): 358-371.
Körner, C. (2007). Climatic treelines: Conventions, global patterns, causes (Klimatische Baumgrenzen: Konventionen, globale Muster, Ursachen). Erdkunde, 61(4): 316-324.

Langham, N. (1983). Distribution and ecology of small mammals in three rain forest localities of Peninsular Malaysia with particular references to Kedah Peak. Biotropica, 15(3): 199-206.

Lim, B. K., \& Pacheco, V. (2016). Small non-volant mammals. In Larsen, T.H. (ed.). Core Standardized Methods for Rapid Biological Field Assessment. Conservation International, Arlington, VA, 84-92.

Lurz, P.W.W., Garson, P.J. \& Wauters, L.A. (1997). Effects of temporal and spatial variation in habitat quality on red squirrel dispersal behaviour. Animal Behaviour, 54(2): 427-435.

McCain, Christy M. \& Grytnes, J.A. (2010) Elevational Gradients in Species Richness. In: Encyclopedia of Life Sciences (ELS). John Wiley \& Sons, Ltd: Chichester.

Nor, S.M. (2001). Elevational diversity patterns of small mammals on Mount Kinabalu, Sabah, Malaysia. Global Ecology and Biogeography, 10(1): 41-62.

Nor, S.M., Batin, Z. \& Akbar, Z. (2001). Elevational diversity pattern of non-volant small mammals on Mount Nuang, Hulu Langat, Selangor. Journal of Biological Sciences, 1(11): 1081-1084.

Norton, D.A. (1985). A multivariate technique for estimating New Zealand temperature normal. Weather and climate, 5(2): 64-74.

Palmiotto, P.A., Davies, S.J., Vogt, K.A., Ashton, M.S., Vogt, D.J. \& Ashton, P.S. (2004). Soil - related habitat specialization in dipterocarp rain forest tree species in Borneo. Journal of Ecology, 92(4): 609. 623.

Payne, J., Francis, C.M. \& Phillips, K. (2005). A Field Guide to the Mammals of Borneo. The Sabah Society, Kota Kinabalu.

Phillips, Q. \& Phillips, K. (2016). Mammals of Borneo and Their Ecology: Sabah, Sarawak, Brunei and Kalimantan. Kota Kinabalu: Natural History Publications.

Richards, P.W., Frankham, R. \& Walsh, R.P.D. (1996). The Tropical Rain Forest: An Ecological Study. Cambridge University Press.

R Core Team (2017). R: A language and environment for statistical computing. R Foundation for Statistical 
Computing, Vienna, Austria. https://www.Rproject. org. Downloaded on 7 April 2021.

Schulze, C.H., Linsenmair, K.E. \& Fiedler, K. (2001). Understorey versus canopy: patterns of vertical stratification and diversity among Lepidoptera in a Bornean rain forest. In Tropical Forest Canopies: Ecology and Management, Pp. 133-152. Springer, Dordrecht.

Stevens, S.M. \& Husband, T.P. (1998). The influence of edge on small mammals: Evidence from Brazilian Atlantic Forest fragments. Biological Conservation, 85(1-2): 1-8.

Theuerkauf, J., Rouys, S., Jourdan, H. \& Gula, R. (2011). Efficiency of a new reverse-bait trigger snap trap for invasive rats and a new standardised abundance index. Annales Zoologici Fennici, 48(5): 308-318.

Umoh, A.A., Akpan, A.O. \& Jacob, B.B. (2013). Rainfall and relative humidity occurrence patterns in uyo metropolis, Akwa Ibom state, South-South Nigeria. IOSR Journal of Engineering, 3(8): 27-31.

Wells, K., Kalko, E.K.V., Lakim, M.B. \& Pfeiffer, M. (2007). Effects of rain forest logging on species richness and assemblage composition of small mammals in Southeast Asia. Journal of Biogeography, 34(6): 1087- 1099.

Wells, K., Corlett, R.T., Lakim, M.B., Kalko, E.K.V. \& Pfeiffer, M. (2009). Seed consumption by small mammals from Borneo. Journal of Tropical Ecology, 25(5): 555-558.
Wen, Z., Quan, Q., Du, Y., Xia, L., Ge, D. \& Yang, Q. (2016). Dispersal, niche, and isolation processes jointly explain species turnover patterns of nonvolant small mammals in a large mountainous region of China. Ecology and Evolution, 6(4): 946-960.

Wickham, H. (2011). ggplot2. Wiley Interdisciplinary Reviews: Computational Statistics, 3(2): 180-185.

William Jr, F., \& Fargo, R.J. (2002). Small mammal populations and ecology in the Kings River Sustainable Forest Ecosystems Project area. In: Verner, Jared, tech. (Ed). Proceedings of a Symposium on the Kings River Sustainable Forest Ecosystem Project: Progress and Current Status. Gen. Tech. Rep. PSW-GTR-183, Albany, CA: Pacific Southwest Research Station, Forest Service, US Department of Agriculture, 183: 133-142.

Zenkova, I.V. \& Rapoport, I.B. (2011). Species richness and high-altitude distribution of earthworms in the Khibiny Massive (Murmansk Region) (Oligochaeta). In: Pavlíček, T., Cardet, P., Almeida, M.T., Pascoal, C., Cássio, F. (Eds.), Advances in Earthworm Taxonomy VI (Annelida: Oligochaeta), Proceedings of the 6th International Oligochaete Taxonomy Meeting (6th IOTM), Palmeira de Faro, Portugal, April 22-25, 2013, Heidelberg: Kasparek Verlag, 141-151. 